\title{
PENGARUH PENGGUNAAN ATLAS ELEKTRONIK TERHADAP HASIL BELAJAR GEOGRAFI DI SMA LABSCHOOL JAKARTA
}

\author{
Eko Tri Rahardjo ${ }^{1}$, Rodiah $^{2}$ \\ Fakultas Ilmu Sosial \\ Universitas Negeri Jakarta \\ Email: ekotri.rahardjo@gmail.com
}

\begin{abstract}
This study aims to get practical answers about the effect of the use of electronic atlases on student learning outcomes in class XI on geography subjects. Research using experimental methods. The population in this study were all students of class XI Labschool Jakarta High School. The sampling technique used is purposive sampling, where one class is an experimental class taught by using an electronic atlas, and another type as a comparison class that is a control class taught not to use an electronic atlas. The instrument used in this study was in the form of multiple-choice tests namely pre-test and post-test. The data analysis technique used to test hypotheses is the t-test.

The results showed that there were differences in student learning outcomes between the experimental class and the control class on natural resource material. Before conducting the hypothesis test, the data requirements test is carried out, namely data normality test using Chi-Square test and data homogeneity test using Bartlet test. From the results of normality test data both pre-test and post-test in the experimental class and the control class obtained prices $X^{2}{ }_{-}{ }_{\text {count }}<X^{2}{ }_{\text {-table, }}$ meaning that the data collected are typically distributed. The results of the homogeneity test data calculations using the Bartlet test also obtained estimates $F^{2}$-count $<F^{2}$-table, eaning that the data from both groups are homogeneous. After testing the data requirements, a hypothesis test is performed using the t-test, and values are obtained tcount $=3,61$ dan $t$-table with $d k 56$, and the 0.05 significance level is 1.67 . So $t$-count $>t$-table means that the alternative hypothesis is accepted, and the null hypothesis is rejected. The results of the study concluded that there is an influence of the use of electronic atlases on the learning outcomes of students of class XI IPS on geography subjects with natural resource material. Therefore, geography study teachers can use this electronic atlas as one of the media used in the learning process of geography.
\end{abstract}

Keywords: Electronic atlas, Geography learning outcomes, Labschool High School Jakarta

\begin{abstract}
Abstrak
Penelitian ini bertujuan untuk mendapatkan jawaban empiris mengenai pengaruh penggunaan atlas elektronik terhadap hasil belajar siswa kelas XI pada mata pelajaran geografi. Penelitian menggunakan metode eksperimen. Populasi dalam penelitian ini adalah semua siswa kelas XI SMA Labschool Jakarta. Teknik pengambilan sampel yang digunakan yaitu purposive sampling, dimana satu kelas merupakan kelas eksperimen yang diajarkan dengan menggunakan atlas elektronik dan satu kelas lagi sebagai kelas pembanding yaitu kelas kontrol yang diajarkan tidak menggunakan atlas elektronik. Instrumen yang digunakan dalam penelitian ini adalah dalam bentuk tes pilihan ganda yaitu pre-tes dan post-tes. Teknik analisa data yang digunakan untuk menguji hipotesis adalah Uji-t. Hasil penelitian menunjukkan bahwa terdapat perbedaan hasil belajar siswa antara kelas eksperimen dan kelas kontrol pada materi sumber daya alam. Sebelum melakukan uji hipotesis terlebih dahulu dilakukan uji persyaratan data yaitu uji normalitas data dengan menggunakan uji Chi Kuadrat dan uji homogenitas data dengan menggunakan uji Bartlet. Dari hasil uji normalitas data baik pre-tes maupun post-tes pada kelas eksperimen dan kelas kontrol diperoleh harga $\mathrm{X}^{2}$-hitung $<\mathrm{X}^{2}$-tabel, artinya data yang diperoleh berdistribusi normal. Hasil perhitungan uji homogenitas data dengan menggunakan uji Bartlet juga diperoleh harga $\mathrm{F}^{2}$-hitung $<\mathrm{F}^{2}{ }_{\text {-tabel, }}$, artinya data dari kedua kelompok tersebut bersifat homogen. Setelah melakukan uji persyaratan data, kemudian dilakukan uji hipotesis dengan menggunakan uji-t dan diperoleh nilai $\mathrm{t}_{\text {-hitung }}=3,61$ dan $\mathrm{t}_{\text {-tabel }}$ dengan dk 56 dan taraf signifikansi 0,05 adalah 1,67. Jadi $t_{\text {-hitung }}>\mathrm{t}$-tabel artinya hipotesis alternatif diterima dan hipotesis nol ditolak. Hasil penelitian menyimpulkan bahwa terdapat pengaruh penggunaan atlas elektronik terhadap hasil belajar siswa kelas XI IPS pada mata pelajaran geografi dengan materi sumber daya alam. Oleh
\end{abstract}


karena itu guru bidang studi geografi dapat menggunakan atlas elektronik ini sebagai salah satu media yang digunakan dalam proses belajar mengajar geografi.

Kata kunci: Atlas elektronik, Hasil belajar Geografi, SMA Labschool Jakarta

\section{PENDAHULUAN}

Guru mata pelajaran geografi yang masih menggunakan metode ceramah tanpa media yang menarik, mengakibatkan materi yang diajarkan menjadi verbal atau hafalan. Akhirnya, geografi hanya dianggap sebagai pengetahuan hafalan yang tidak memerlukan pemahaman. Apalagi jika guru kurang memberikan informasi yang lengkap, maka siswa menjadi kurang memahami konsep pengajaran. Dari permasalahan tersebut, sebenarnya ada satu masalah utama yang perlu mendapat perhatian, yaitu kemampuan guru memaksimalkan hasil belajar siswa pada pelajaran. Metode apapun yang digunakan dalam pengajaran geografi terutama geografi fisik, tanpa menggunakan media, tidak akan dapat berhasil dengan baik. Dalam pelajaran geografi gejala-gejala dan proses-proses alamiah adalah situasi nyata yang tidak selalu dapat disediakan oleh guru baik di kelas maupun di lingkungannya. Untuk itu diperlukan media pembelajaran yang dapat memberikan gambaran atau contoh situasi nyata dalam sajian tayangan hidup.
Dalam Kurikulum Tingkat Satuan Pendidikan untuk Sekolah Menengah Atas, Materi Pembelajaran Persebaran dan Pemanfaatan Sumber Daya Alam dengan standar kompetensi memahami sumber daya alam pada kelas XI. Materi tersebut merupakan salah satu materi pelajaran geografi yang menuntut tersedianya sumber belajar yang berupa media yang dapat menggambarkan sebaran sumber daya alam khususnya di Indonesia.

Media yang dapat menggambarkan sebaran sumber daya alam dapat berupa gambar, yang ditampilkan dalam bentuk peta maupun atlas. Namun jenis-jenis media tersebut sulit menampilkan gerak sehingga kurangnya minat siwa untuk mengerti dan mempelajari atlas sebagai sumber informasi penting yang berkaitan dengan sumber daya alam khususnya di Indonesia.

Film dan video dapat menampilkan obyek yang bergerak bersama-sama dengan suara alamiah yang sesuai dan dapat memberinya daya tarik tersendiri. Salah satu media audio visual yang saat ini sangat populer digunakan dalam dunia pendidikan adalah audiovisual 
interaktif yang direkam dalam Compact Disk (CD). CD dapat mengakses berbagai macam data dan obyek yang tidak dapat dilihat secara langsung, karena faktor lokasi yang jauh atau proses yang memakan waktu sangat lama. CD dapat dilengkapi dengan narasi atau suara lain yang dapat ditangkap dengan indera pendengaran. CD pembelajaran semacam ini disebut dengan $\mathrm{CD}$ pembelajaran interaktif dengan program Macromedia flash .

Macromedia flash merupakan aplikasi yang digunakan untuk melakukan desain dan membangun perangkat presentasi, publikasi, atau aplikasi lainnya yang membutuhkan ketersediaan sarana interaksi dengan penggunanya (Wahyono, 2006 : 1). Proyek yang dibangun dengan Flash bisa terdiri atas teks, gambar, animasi sederhana, video, atau efek-efek khusus lainnya. Salah satu produk yang dihasilkan dengan program Macromedia flash adalah atlas elektronik. Atlas elektronik merupakan salah satu produk Pusat Atlas Bakosurtanal, yang dikemas dalam bentuk CD ROM, dan berisi informasi mengenai sumber daya alam di Indonesia.

Penggunaan media berbasis teknologi informasi di berbagai sekolah belum sepenuhnya terlaksana. Kendala yang utama adalah ketersediaan media serta alat-alat yang mendukung. Akan tetapi penggunaan media ini sudah diterapkan dibeberapa sekolah baik sekolah swasta maupun sekolah negeri. Salah satu sekolah yang sudah menggunakan media berbasis teknologi informasi adalah SMA Labshcool Jakarta. Dalam hal ini, SMA Labschool Jakarta telah menerapkan penggunaan media berbasis teknologi informasi dalam proses pembelajaran, akan tetapi berdasarkan observasi awal penulis, pada saat ini penggunaan atlas elektronik belum digunakan oleh guru geografi sebagai media pembelajaran. Untuk itu, penggunaan atlas elektronik ini diharapkan dapat mendukung dalam penerapan pembelajaran multimedia berbasis teknologi informasi.

Kata media berasal dari bahasa latin medius yang secara harfiah memiliki arti perantara atau pengantar. Gerlach dan Ely mengatakan bahwa media apabila dipahami secara garis besar adalah manusia, materi, atau kejadian yang membangun kondisi yang membuat siswa mampu memperoleh pengetahuan, keterampilan, atau sikap (Arsyad, 2009 : 3). Sedangkan menurut 
Association for Education and dapat disimpulkan bahwa media Communication Technology (AECT) pembelajaran adalah segala bentuk dalam Arsyad (2009 : 3), media dapat diibaratkan sebagai segala bentuk yang digunakan untuk proses penyaluran informasi. Sedangkan Gagne menyatakan bahwa media adalah berbagai jenis komponen dalam lingkungan siswa yang dapat merangsangnya untuk belajar (Sadiman, $2008: 6)$.

Disamping sebagai sistem penyampai atau pengantar, media yang sering diganti dengan kata mediator menurut Fleming dalam Arsyad (2009 : 3) adalah penyebab atau alat yang turut campur tangan dalam dua pihak dan mendamaikannya. Heinich, dan kawankawan dalam Arsyad (2009 : 4) mengemukakan istilah medium sebagai perantara yang mengantar informasi antara sumber dan penerima. Sejalan dengan batasan ini, Hamidjojo dalam Arsyad (2009 : 4) memberi batasan media sebagai semua bentuk perantara yang digunakan oleh manusia untuk menyampaikan atau menyebar ide, gagasan, atau pendapat sehingga ide, gagasan atau pendapat yang dikemukakan itu sampai kepada penerima yang dituju. Dari beberapa pengertian mengenai media di atas, sarana yang dapat digunakan dalam menyampaikan pesan berupa bahan pelajaran dari seorang guru kepada peserta didiknya yaitu siswa sehingga tujuan pembelajaran dapat tercapai. Penggunaan media dalam pembelajaran yang kreatif dapat memudahkan siswa menyerap informasi yang disampaikan sehingga siswa dapat belajar lebih banyak dan mengingatnya dengan baik.

Pemilihan media yang tepat dalam proses belajar mengajar dapat memudahkan siswa untuk menyerap berbagai informasi. Oleh karena itu, tidak semua mata pelajaran dapat menggunakan media yang sama, akan tetapi harus sesuai dengan kompetensi dan indikator pembelajaran yang ingin dicapai. Pengajaran geografi pada hakikatnya adalah pengajaran tentang gejala-gejala geografi di permukaan bumi. Lingkungan yang ada di sekitar adalah salah satu sumber yang dapat dimanfaatkan untuk menunjang kegiatan belajar. Siswa dapat dihadapkan pada keadaan yang sebenarnya, keadaan yang alami, sehingga lebih nyata, lebih faktual dan lebih dapat dipertanggungjawabkan. Namun mengingat adanya keterbatasanketerbatasan yang tidak memungkinkan 
membawa siswa ke obyek langsung yang dipelajari, maka obyeknyalah yang dibawa ke siswa. Keterbatasan tersebut dapat disebabkan obyeknya terlalu besar atau terlalu kecil, obyek yang bergerak terlalu lambat atau terlalu cepat, obyek yang terlalu kompleks dan obyek yang mengandung bahaya dan resiko tinggi. Obyek yang dimaksud dapat berupa miniatur, model, maupun gambar yang disajikan secara visual, auditif, maupun audiovisual.

Media yang utama dalam pembelajaran geografi adalah model permukaan bumi yang berupa peta, atlas dan globe. Pta merupakan konsep (round earth on the flat paper) dan hakikat dasar pada geografi dan pengajaran geografi. Sedangkan atlas adalah kumpulan peta dalam bentuk buku. Dalam atlas ini disajikan berbagai peta berdasarkan kenegaraan, gejala alam, penyebaran sumber daya, penyebaran aspek kebudayaan, dan lain sebagainya (Sumaatmaja, 2001 : 79). Oleh karena itu, mengajarkan dan mempelajari geografi tanpa peta maupun atlas, tidak akan membentuk citra dan konsep yang baik pada diri siswa yang mempelajarinya.

Pada perkembangannya yang terakhir, peta, atlas, maupun model yang dapat menggambarkan proses-proses yang terjadi di alam dapat ditampilkan dengan teknologi komputer. Dalam pembelajaran telah banyak dikenal media dan interaktif yang dikendalikan dengan komputer. Dalam hal ini, Bakosurtanal telah memproduksi atlas elektronik. Atlas elektronik merupakan salah satu produk Pusat Atlas Bakosurtanal, yang dikemas dalam bentuk CD ROM, dan berisi informasi mengenai sumber daya alam di Indonesia. Dari berbagai klasifikasi macam-macam media yang telah disebutkan sebelumnya, dapat disimpulkan bahwa media atlas elektronik tergolong teknologi mutakhir berbasis komputer dengan jenis audiovisual. Selain itu, atlas elektronik tergolong media untuk pengajaran individual. Dalam pengguanaanya, atlas elektronik yang berbentuk CD dapat dilakukan secara individual dengan berprogram dan pengajaran melalui komputer. Dalam pembuatannya, atlas elektronik tergolong media kompleks. Bahan dan alat pembuatan atlas elektronik sangat sulit diperoleh, sulit membuatnya dan memerlukan keterampilan yang memadai. Tampilan tayangan yang berwarna, penyertaan pemodelan sebagai jembatan ke arah 
pemahaman, diasumsikan mempermudah dan mempercepat siswa menyerap materi pembelajaran. Dengan asumsi tersebut atlas elektronik akan mempermudah pembelajaran. Dalam pembelajaran, atlas elektronik dapat menggambarkan suatu objek yang bergerak bersama-sama dengan suara alamiah atau suara yang sesuai. Kemampuan media audio visual melukiskan gambar hidup dan suara memberikan daya tarik tersediri karena dapat menyajikan informasi, memaparkan proses, menjelaskan konsep-konsep yang rumit, mengajarkan ketrampilan, menyingkat atau memperpanjang waktu, dan mempengaruhi sikap.

Dalam proses pembelajaran guru perlu memberikan berupa rangsangan seperti media agar siswa dapat merespon dengan baik. Mengacu pada teori Petrovich Pavlov (Suryabrata, 1993 : 281) mengenai stimulus-respon, guru dapat memberikan stimulus berupa atlas elektronik kepada siswa agar siswa memberi respons terhadap stimulus yang diberikan. Media mampu memberiakan rangsangan yang bervariasi kepada otak kita, sehingga otak kita dapat berfungsi secara optimal. Penelitian yang dilakukan oleh Roger W.
Sperry, pemenang Nobel tahun 1984 (Miarso, 2005 : 458) menunjukan bahwa belahan otak sebelah kiri merupakan tempat kedudukan pikiran yang bersifat verbal, rasional, antalitikal, dan konseptual. Belahan ini mengontrol wicara. Belahan otak sebelah kanan merupakan tempat kedudukan pikiran visual, emosional, holistik, fisikal, spatial, dan kreatif. Belahan ini mengontrol tindakan. Pada suatu saat yang dominan; kedua belahan tidak dapat dominan secara serentak. Rangsangan pada salah satu belahan saja secara berkepanjangan akan menyebabkan ketegangan. Karena itu, sebagai salah satu implikasi dalam pembelajaran ialah kedua belahan perlu dirangsang bergantian dengan rangsangan audio dan visual. Dale dalam Arsyad (2009 : 10) mengatakan juga bahwa pemerolehan hasil belajar melalui indera pandang berkisar $75 \%$, melalui indera dengar sekitar $13 \%$ dan melalui indera lainnya sekitar 12\%. Apabila media atlas elektronik sebagai media pembelajaran, maka akan berdampak pada hasil belajar yang lebih baik

Atlas elektronik yang berupa media audiovisual berbentuk compact disk, yang dalam sistem penyimpanan signal audiovisual direkam pada disket 
plastik, sehingga Video Compact Disk dapat berfungsi sebagai media pandang dengar (audiovisual). Karena atlas elektronik disimpan dalam bentuk CD, maka perlu diuraikan kelebihan dan kelemahannya. Menurut Bastable (2002 : 338), kelebihan utama CD adalah ketepatannya yang nyata dan tidak berkurang setelah waktu yang lama. Keuntungan terbesar dari penggunaannya adalah kepraktisannya. Ukurannya kecil, portabel, mudah disiapkan atau digandakan. CD juga dapat menjadi alat yang kuat untuk menunjang metode pengajaran lain kerena memberikan pendengaran (audio) maupun penglihatan (visual). Selain itu dapat memberikan informasi yang berulang-ulang. Kekurangan CD masih relatif mahal. Disamping itu, tidak banyak orang atau lembaga memiliki perangkat keras recorder atau kemampuan menggunakan komputer untuk mengakomodasi pemakaian alat ini. Dengan demikian, diantara kelebihannya itu masih terbatas penerapannya di bidang pendidikan. Namun, dengan kemajuan teknologi penggunaan $\mathrm{CD}$ dapat diterapkan di dunia pendidikan.

Atlas elektronik yang dimaksud peneliti adalah media CD interaktif dengan program Macromediaflash yang menggambarkan secara lengkap sebaran sumber daya alam di Indonesia. Atlas tersebut disajikan dengan pengendalian komputer kepada siswa. Guru menyiapkan peralatan untuk memutar CD yang berupa komputer dengan LCD. Tugas siswa mempelajari dengan melihat serta mengamati sebaran sumber daya alam yang disajikan dalam program. Apabila siswa kurang jelas maka dapat ditampilkan kembali sehingga akan memudahkan guru untuk menambah penjelasan. Dari penggunaannya, komputer sebagai alat pengendali $\mathrm{CD}$, memiliki kelebihan dan kekurangan (Arsyad, 2009 : 54), kelebihannya antara lain Komputer dapat mengakomodasi siswa yang lamban menerima pelajaran; Komputer dapat merangsang siswa untuk mengerjakan latihan, melakukan kegiatan atau simulasi karena tersedianya animasi, grafik, warna dan musik yang dapat menambah realisme; Kendali berada di tangan siswa sehingga tingkat kecepatan belajar disesuaikan dengan sekolah masing-masing; Kemampuan merekam keinginan siswa selama menggunakan suatu program; Dapat berhubungan dengan dan mengendalikan peralatan lain seperti compact disk. Dari beberapa 
kelebihan komputer sebagai alat pengendali $\mathrm{CD}$, dalam penggunaannya memiliki beberapa kelemahan, antara lain pengembangan perangkat lunak masih mahal; Untuk menggunakan komputer perlu pengetahuan dan keterampilan khusus; Keragaman model komputer sering menyebabkan program (software) yang tersedia untuk satu model tidak cocok (kompatibel) dengan model lainnya.

Dengan demikian atlas elektronik merupakan media yang terintegrasi dengan media-media lain sebagi pendukungnya seperti CD maupun Komputer. Dengan penggunaan atlas elektronik ini dalam pembelajaran geografi memungkinkan terjadinya interaksi langsung antara siswa dengan materi pelajaran, khususnya materi sumber daya alam. Dan karena melalui media ini siswa akan memperoleh pengalaman lebih luas dan lebih lengkap. Keluasan materi yang didapat oleh siswa ini akan menimbulkan minat belajar yang baru dan konsep yang dijelaskan oleh media dapat disajikan dengan rekreatif dan menarik sehingga akan mampu meningkatkan capaian hasil belajar siswa. Hasil Belajar menurut Purwanto (2010 : 34) adalah perubahan perilaku siswa akibat belajar. Perubahan itu diupayakan dalam proses belajar mengajar untuk mencapai tujuan pendidikan. Perubahan perilaku individu akibat proses belajar tidaklah tunggal. Setiap proses belajar mempengaruhi perubahan perilaku dominan tertentu pada diri siswa, tergantung perubahan yang diinginkan terjadi sesuai dengan tujuan pendidikan.

Dalam sistem pendidikan nasional, pengklasifikasian hasil belajar yang diadopsi adalah klasifikasi yang dikemukakan oleh Bloom dalam Sudjana (2010 : 22), secara garis besar membagi hasil belajar menjadi 3 ranah, yaitu kognitif, afektif dan psikomotorik. Untuk mengukur aspek kognitif dilakukan melalui tes, untuk mengukur aspek afektif data dilakukan melalui skala sikap dan untuk menguji aspek psikomotorik dapat dilakukan dengan ujian tindakan.

Hasil belajar merupakan realisasi tercapainnya tujuan pendidikan, sehingga hasil belajar yang diukur sangat tergantung kepada tujuan pendidikannya (Purwanto, 2010 : 47). Tujuan pembelajaran geografi adalah untuk peningkatan kemampuan kognitif, afektif dan psikomotor. Dengan mempelajari geografi, siswa dapat 
meningkatkan kemampuan, pengetahuan dan keilmuan yang dimiliki untuk menjalani hidup yang penuh masalah dan tantangan alam. Kemampuan intelektual siswa yang mempelajarinya dapat meningkatkan rasa ingin tahu, daya untuk melakukan observasi alam dan lingkungan, melatih ingatan dan citra terhadap kehidupan dengan lingkungannya dan dapat melatih kemampuan memecahkan masalah kehidupan yang terjadi sehari-hari atau secara gamblang memiliki nilai edukatif tinggi (Sumaatmadja, $2001: 20$ ).

\section{METODOLOGI PENELITIAN}

Penelitian ini bertujuan untuk mendapatkan jawaban empiris mengenai pengaruh penggunaan atlas elektronik terhadap hasil belajar siswa kelas XI pada mata pelajaran geografi. Penelitian menggunakan metode eksperimen. Populasi dalam penelitian ini adalah semua siswa kelas XI SMA Labschool Jakarta.

Teknik pengambilan sampel yang digunakan yaitu purposive sampling, dimana satu kelas merupakan kelas eksperimen yang diajarkan dengan menggunakan atlas elektronik dan satu kelas lagi sebagai kelas pembanding yaitu kelas kontrol yang diajarkan tidak menggunakan atlas elektronik. Instrumen yang digunakan dalam penelitian ini adalah dalam bentuk tes pilihan ganda yaitu pre-tes dan post-tes. Teknik analisa data yang digunakan untuk menguji hipotesis adalah Uji-t.

\section{HASIL DAN PEMBAHASAN}

1. Hasil Pre tes Kelas Eksperimen dan Kelas Kontrol

a. Hasil Pre tes Kelas Eksperimen
Kelas eksperimen merupakan kelas tempat dilakukannya penerapan atlas elektronik. Berdasarkan data yang dikumpulkan pada saat pre tes dengan jumlah 29 siswa, nilai terendah yang diperoleh siswa pada kelas eksperimen adalah 43 sedangkan nilai tertinggi pada kelas eksperimen adalah 70. Dari hasil pre tes tersebut diperoleh rata-rata kelas 54,48. Simpangan baku sebesar 7,72 menunjukkan derajad perbedaan atau variasi nilai individu dalam kelompok. Berdasarkan perhitungan, diperoleh nilai pre tes yang didapat oleh siswa pada kelas eksperimen pada interval antara 68 - 72 memiliki frekuensi 2 siswa atau $6,9 \%$. Sedangkan untuk siswa yang memperoleh nilai pada interval antara 43 - 47 memiliki frekuensi sebanyak 6 siswa atau $20,7 \%$. Selain itu, perolehan nilai dengan jumlah siswa terbanyak 
yaitu 8 siswa atau sebanyak 27,6\% dari jumlah total yang berada pada interval nilai 53 - 57, sedangkan perolehan nilai siswa dengan jumlah siswa paling sedikit yaitu hanya 2 siswa atau sebanyak 6,9\% berada pada nilai antara 58 - 62 dan 68 72. Dari data pre tes di atas menunjukkan bahwa kemampuan awal siswa pada kelas eksperimen ini dapat dikatakan sudah cukup baik, karena nilai rata-rata pre tesnya adalah 54,48. Artinya sebagian dari jumlah soal yang ada sudah dapat dijawab oleh siswa dengan baik. Hal ini menunjukkan bahwa daya ingat siswa mengenai materi sumber daya alam yang pernah mereka peroleh di bangku SMP masih cukup baik.

b. Hasil Pre tes Kelas Kontrol

Dari data yang dikumpulkan pada saat pre tes dengan jumlah 29 siswa, diperoleh nilai terendah untuk kelas kontrol adalah 43 dan nilai tertinggi 70 . Dari hasil tersebut diperoleh nilai ratarata 56,21. Simpangan baku sebesar 7,27 menunjukkan derajad perbedaan atau variasi nilai individu dalam kelompok. Dari perhitungan ini, dapat diketahui bahwa nilai pre tes yang diperoleh siswa pada kelas kontrol pada interval antara 43 - 47 memiliki frekuensi 4 siswa atau $13,8 \%$, sedangkan untuk siswa yang memperoleh nilai pada interval antara $68-72$ memiliki frekuensi 2 siswa atau sebesar $6,9 \%$. Selain itu, perolehan nilai dengan jumlah siswa terbanyak yaitu 11 siswa atau sebanyak 37,9\% dari jumlah total berada pada interval nilai $53-57$, sedangkan perolehan nilai siswa dengan jumlah siswa paling sedikit yaitu hanya 2 siswa atau sebanyak $6,9 \%$ berada pada nilai antara 68 - 72. Berdasarkan data pre tes tersebut, dapat dilihat bahwa kemampuan awal siswa pada kelas kontrol ini sudah cukup baik, karena hampir sebagian dari jumlah siswa yaitu sekitar 21 siswa memperoleh nilai di atas 50. Hal ini memperlihatkan bahwa lebih dari 50\% siswa sudah bisa menjawab setengah dari jumlah soal yang ada dengan baik. Dari hasil pre tes yang ada, kemampuan awal kelas eksprimen dan kelas kontrol ini dapat dikatakan hampir sama. Terlihat dari nilai yang diperoleh siswa pada kelas eksperimen dan kelas kontrol yang tidak jauh berbeda.

2. Hasil Post tes Kelas Eksperimen dan Kelas Kontrol

a. Hasil Post tes Kelas Eksperimen Berdasarkan pada data post tes kelas eksperimen, nilai terendah untuk kelas eksperimen adalah 63 sedangkan nilai tertinggi kelas eksperimen adalah 90. Dari hasil tersebut diperoleh rata-rata 
80,17. Simpangan baku sebesar 7,62 menunjukkan derajad perbedaan atau variasi nilai individu dalam kelompok. Dari hasil ini diketahui bahwa rata-rata nilai siswa mengalami peningkatan antara sebelum dan sesudah perlakuan. Jika pada saat pre tes diperoleh rata-rata sebesar 54,48 kemudian mengalami peningkatan pada saat post tes menjadi 80,17 . Selisih antara nilai rata-rata siswa pada saat pre tes dan nilai rata-rata siswa pada saat post tes adalah sebesar 25,69. Hasil yang diperoleh dari penghitungan ini bahwa nilai post tes yang diperoleh siswa pada interval 63-67 memiliki frekuensi 3 siswa atau 10,3\% dan pada interval antara $88-92$ memiliki frekuensi 4 siswa atau sebesar 13,8\%. Selain itu, terlihat juga bahwa perolehan nilai dengan jumlah siswa terbanyak yaitu 10 siswa atau 34,5\% dari jumlah total, berada pada interval nilai $83-87$, sedangkan sebanyak perolehan nilai siswa dengan jumlah siswa paling sedikit yaitu hanya 2 siswa atau sebanyak 6,9\% berada pada nilai antara 68 - 72. Dari data post tes kelas eksperimen, menunjukkan bahwa terjadi peningkatan nilai $20 \%$ antara sebelum dan sesudah perlakuan. Artinya nilai post tes lebih tinggi dibandingkan dengan nilai pre tes. Jika pada saat pre tes nilai tertinggi yang dicapai oleh siswa yaitu 70 maka pada saat post tes nilai tertinggi yang dicapai siswa adalah 90. Begitu juga untuk nilai terendah, pada saat pre tes nilai terendah yang diperoleh siswa yaitu 43 kemudian pada saat post tes nilai terendah yang diperoleh siswa adalah 63. Peningkatan nilai pada kelas eksperimen ini salah satunya dikarenakan penggunaan media belajar yaitu atlas elektronik pada saat proses belajar mengajar berlangsung. Dengan penggunaan atlas elektronik ini siswa menjadi lebih tertarik untuk memperlajari materi yang disampaikan oleh guru sehingga berpengaruh pada peningkatan nilai siswa.

\section{b. Hasil Post tes Kelas Kontrol}

Dari hasil post tes kelas kontrol dengan jumlah 29 siswa, diperoleh nilai terendah 60 sedangkan nilai tertinggi adalah 83. Dari hasil perhitungan diperoleh rata-rata 72,81 . Simpangan baku sebesar 6,31 menunjukkan derajad perbedaan atau variasi nilai individu dalam. Berdasarkan data tersebut diketahui bahwa nilai rata-rata siswa pada kelas kontrol juga mengalami peningkatan. Jika pada saat pre tes diperoleh rata-rata sebesar 56,21 kemudian mengalami peningkatan pada saat post tes menjadi 72,81. Selisih antara nilai rata-rata siswa pada saat pre 
tes dan nilai rata-rata siswa pada saat post tes adalah sebesar 13,6. Berikut ini disajikan tabel distribusi frekuensi. Berdasarkan hasil ini, nilai post tes yang diperoleh siswa pada kelas kontrol pada interval $60-63$ memiliki frekuensi 3 siswa atau $10,3 \%$ dan nilai pada interval antara $80-83$ memiliki frekuensi 5 siswa atau $17,2 \%$. Selain itu, terlihat juga bahwa perolehan nilai dengan jumlah siswa terbanyak yaitu 8 siswa atau $27,6 \%$ dari jumlah total, berada pada interval nilai 76 - 79, sedangkan sebanyak perolehan nilai siswa dengan jumlah siswa paling sedikit yaitu hanya 3 siswa atau sebanyak $10 \%$ berada pada nilai antara 63 - 67. Dari data post tes pada kelas kontrol ini juga menunjukkan adanya peningkatan nilai antara sebelum dan sesudah pengajaran. Hal ini dapat dilihat dari nilai terendah pada saat pre tes adalah 43 sedangkan pada saat post tes nilai terendahnya yaitu 60. Begitu juga untuk nilai tertinggi, pada saat pre tes nilai tertingginya adalah 70 sedangkan pada saat post tes menjadi 83. Dari hasil post tes tersebut memperlihatkan bahwa peningkatan nilai pada kelas eksperimen lebih tinggi dibandingkan dengan kelas kontrol. Hal ini dikarenakan pada kelas eksperimen pada proses belajar mengajar menggunakan atlas elektronik, sedangkan pada kelas kontrol proses belajar mengajar menggunakan atlas, sehingga siswa menjadi kurang termotivasi untuk belajar dan merasa bosan. Kondisi seperti inilah yang pada akhirnya berpengaruh pada perolehan hasil belajar siswa.

3. Hasil Skor Pre tes dan Post tes Per Materi Pelajaran

a. Hasil Skor Soal Materi Pengertian Sumber Daya Alam

Soal yang berisi materi pengertian sumber daya alam pada kelas kontrol dan ekperimen menjelaskan pengertian sumber daya alam serta mengidentifikasi faktor-faktor yang berpengaruh terhadap keberadaan flora dan fauna. Secara garis besar, hasil skor soal materi pengertian sumber daya alam pada kelas eksperimen maupun kontrol dapat dilihat pada tabel di bawah ini : 
Tabel 1. Hasil Skor Soal Materi Pengertian Sumber Daya Alam

\begin{tabular}{lllll}
\hline \multirow{2}{*}{$\begin{array}{l}\text { No. } \\
\text { Soal }\end{array}$} & Kelompok & \multicolumn{2}{l}{ Pengertian SDA } & \\
\cline { 2 - 5 } & Pre tes & & Post tes & \\
\cline { 2 - 5 } & Kontrol & Eksperimen & Kontrol & Eksperimen \\
\hline 1 & 29 & 29 & 29 & 29 \\
2 & 28 & 27 & 29 & 28 \\
3 & 5 & 14 & 25 & 20 \\
5 & 14 & 13 & 23 & 19 \\
\hline Skor & 76 & 83 & 106 & 96 \\
\hline Rata-Rata & 19,0 & 20,8 & 26,5 & 24,0 \\
\hline
\end{tabular}

Berdasarkan tabel diatas, soal yang mengidentfikasi dan menjelaskan sumber daya alam berjumlah 4 soal. Skor pre tes pada kelas eksperimen sebesar 83 sedangkan pada kelas kontrol sebesar 76. Pada saat post tes, skor kelas eksperimen sebesar 96 sedangkan pada kelas kontrol sebesar 106. Berdasarkan skor pre tes pada kelas eksperimen lebih tinggi dibandingkan kelas kontrol, akan tetapi pada jumlah post tes pada kelas kontrol lebih tinggi dibandingkan kelas eksperimen.

Pada dua kelas ini, baik kelas eksperimen maupun kontrol mengalami peningkatan. Hal ini ditunjukan pada rata-rata skor kelas eksperimen pada saat pre tes sebesar 20,8 dan pada saat post tes sebesar 24. Dan pada kelas kontrol rata-rata skor pre tes sebesar 19 dan ratarata skor post tes sebesar 26,5. Pada kelas eksperimen mengalami peningkatan sebesar 3,2 dan pada kelas kontrol mengalami peningkatan sebesar 7,5 .

b. Hasil Skor Soal Materi Jenis-Jenis Sumber Daya Alam

Soal yang berisi materi jenis-jenis sumber daya alam, mengidentifikasikan jenis-jenis sumber daya alam berdasarkan potensinya. Secara garis besar, hasil skor soal materi jenis-jenis sumber daya alam pada kelas eksperimen maupun kontrol dapat dilihat pada tabel di bawah ini : 
Tabel 2. Hasil Skor Soal Materi Jenis-Jenis Sumber Daya Alam

\begin{tabular}{lllll}
\hline \multirow{2}{*}{ No. Kelompok Soal } & \multicolumn{2}{l}{ Jenis-Jenis SDA } & & \\
\cline { 2 - 5 } & Pre tes & & Post tes & \\
\cline { 2 - 5 } & Kontrol & Eksperimen & Kontrol & Eksperimen \\
\hline 4 & 29 & 25 & 29 & 26 \\
6 & 14 & 20 & 18 & 19 \\
7 & 11 & 15 & 24 & 22 \\
8 & 14 & 16 & 24 & 27 \\
9 & 18 & 16 & 21 & 25 \\
10 & 28 & 25 & 28 & 27 \\
11 & 10 & 9 & 19 & 12 \\
12 & 14 & 20 & 22 & 24 \\
\hline Skor & 138 & 146 & 185 & 182 \\
\hline \multirow{2}{*}{ Rata-Rata } & 17,3 & 18,3 & 23,1 & 22,8 \\
\hline
\end{tabular}

Berdasarkan tabel diatas, soal yang mengidentifikasikan jenis-jenis sumber daya alam berjumlah 8 soal. Skor pre tes pada kelas eksperimen sebesar 146 sedangkan pada kelas kontrol sebesar 138. Pada saat post tes, skor kelas eksperimen sebesar 182 sedangkan pada kelas kontrol sebesar 185. Berdasarkan skor pre tes pada kelas eksperimen lebih tinggi dibandingkan kelas kontrol, akan tetapi pada skor post tes pada kelas kontrol lebih tinggi dibandingkan kelas eksperimen. Kelas eksperimen maupun kontrol mengalami peningkatan. Hal ini ditunjukan pada rata-rata skor kelas eksperimen pada saat pre tes sebesar 18,3 dan pada saat post tes sebesar 22,8. Dan pada kelas kontrol rata-rata skor pre tes sebesar 17,3 dan pada saat post tes sebesar 23,1. Pada kelas eksperimen mengalami peningkatan sebesar 4,5 dan pada kelas kontrol mengalami peningkatan sebesar 5,8.

c. Hasil Skor Soal Materi Persebaran Sumber Daya Alam

Soal yang berisi materi persebaran sumber daya alam, mendeskripsikan peta persebaran sumber daya alam Indonesia. Pada materi ini, antara kelas eksperimen dan kelas kontrol diberikan perlakuan yang berbeda. Kelas eksperimen diberikan perlakuan atlas elektronik sedangkan pada kelas kontrol tidak diberikan perlakuan atau hanya diberikan penjelasan sebagaimana biasanya dengan menggunakan atlas. Sehingga hasil skor pada kelas eksperimen maupun kontrol berbeda. Untuk lebih jelasnya dapat dilihat pada tabel di bawah ini : 
Tabel 3. Hasil Skor Soal Materi Persebaran Sumber Daya Alam

\begin{tabular}{lllll}
\hline \multirow{2}{*}{$\begin{array}{l}\text { No. } \\
\text { Soal }\end{array}$} & Kelompok & \multicolumn{3}{l}{ Persebaran SDA } \\
\cline { 2 - 5 } & Pre tes & Pksperimen & Kontrol & Eksperimen \\
\cline { 2 - 5 } & Kontrol & 17 & 16 & 28 \\
\hline 13 & 13 & 1 & 15 & 23 \\
14 & 1 & 9 & 19 & 27 \\
15 & 12 & 10 & 20 & 28 \\
16 & 13 & 5 & 20 & 26 \\
17 & 8 & 13 & 15 & 24 \\
18 & 10 & 6 & 15 & 24 \\
19 & 3 & 61 & 120 & 180 \\
\hline Skor & 60 & 8,7 & 17,1 & 25,7 \\
\hline Rata-Rata & 8,6 & & & \\
\hline
\end{tabular}

Berdasarkan tabel diatas, soal yang mendeskripsikan peta persebaran sumber daya alam Indonesia berjumlah 7 soal. Skor pre tes pada materi persebaran sumber daya alam pada kelas eksperimen sebesar 61 sedangkan pada kelas kontrol sebesar 60. Pada saat post tes, skor kelas eksperimen sebesar 180 sedangkan pada kelas kontrol sebesar 120. Berdasarkan skor pre tes maupun post tes pada kelas eksperimen lebih tinggi dibandingkan kelas kontrol. Pada kelas eksperimen maupun kontrol mengalami peningkatan. Hal ini ditunjukan pada rata-rata skor kelas eksperimen pada saat pre tes sebesar 8,7 dan pada saat post tes sebesar 25,7. Dan pada kelas kontrol rata-rata skor pre tes sebesar 8,6 dan rata-rata skor post tes sebesar 17,1. Pada kelas eksperimen mengalami peningkatan sebesar 17 dan pada kelas kontrol mengalami peningkatan sebesar 8,5. Pada materi persebaran sumber daya alam peningkatan kelas eksperimen lebih besar dibandingkan kelas kontrol.

d. Hasil Skor Soal Materi Pemanfaatan Sumber Daya Alam

Soal yang berisi materi mengenai pemanfaatan sumber daya alam, mendeskripsikan pemanfaatan sumber daya alam berdasarkan prinsip ekoefisiensi, pembangunan berkelanjutan dan mengidentifikasikan ciri-ciri pengelolaan sumber daya alam berwawasan lingkungan. Hasil Soal tersebut dapat dilihat pada tabel di bawah ini: 
Tabel 4. Hasil Skor Soal Materi Pemanfaatan Sumber Daya Alam

\begin{tabular}{lllll}
\hline \multirow{2}{*}{$\begin{array}{l}\text { No. } \\
\text { Soal }\end{array}$} & Kelompok & \multicolumn{3}{l}{ Pemanfaatan SDA } \\
\cline { 2 - 5 } & Pre tes & \multicolumn{3}{l}{ Post tes } \\
\cline { 2 - 5 } 20 & Kontrol & Eksperimen & Kontrol & Eksperimen \\
21 & 21 & 14 & 25 & 26 \\
22 & 17 & 14 & 18 & 24 \\
23 & 27 & 24 & 17 & 23 \\
24 & 14 & 8 & 19 & 18 \\
25 & 25 & 18 & 25 & 25 \\
26 & 9 & 15 & 16 & 23 \\
27 & 13 & 18 & 16 & 15 \\
28 & 27 & 27 & 25 & 28 \\
29 & 17 & 18 & 25 & 27 \\
30 & 23 & 20 & 17 & 20 \\
\hline Skor & 19 & 10 & 19 & 15 \\
\hline Rata-Rata & 212 & 186 & 222 & 244 \\
\hline
\end{tabular}

Berdasarkan tabel di atas, soal yang menjelaskan pemanfaatan sumber daya alam berjumlah 11 soal. Skor pre tes pada kelas eksperimen sebesar 186 sedangkan pada kelas kontrol sebesar 212. Pada kelas eksperimen skor post tes sebesar 244 sedangkan pada kelas kontrol sebesar 222. Berdasarkan skor pre tes pada kelas kontrol lebih tinggi dibandingkan kelas eksperimen akan tetapi pada skor post tes pada kelas eksperimen lebih tinggi dibandingkan kelas kontrol. Pada kelas eksperimen dan kontrol mengalami peningkatan. Hal ini ditunjukan pada rata-rata skor kelas eksperimen pada saat pre tes sebesar 16,9 dan pada saat post tes sebesar 22,2.
Dan pada kelas kontrol rata-rata skor pre tes sebesar 19,3 dan rata-rata skor post tes sebesar 20,2. Pada kelas eksperimen mengalami peningkatan sebesar 5,3 dan pada kelas kontrol mengalami peningkatan sebesar 0,9 .

Penelitian eksperimen ini menggunakan instrumen tes. Tes dilakukan sebanyak dua kali, yaitu pre tes dilakukan untuk mengetahui kemampuan awal siswa dan post tes dilakukan untuk mengetahui kemampuan akhir siswa setelah melakukan proses pembelajaran. Instrumen tes tertulis berbentuk pilihan ganda dengan lima option atau pilihan jawaban dan berisi 30 butir item soal yang telah diuji validitasnya. Untuk 
setiap jawaban yang benar diberi skor 1 dan untuk setiap jawaban yang salah diberi skor 0 . Tes ini disusun berdasarkan standar kompetensi, kompetensi dasar dan indikator pada mata pelajaran Geografi SMA kelas XI semester 2 dengan materi sumber daya alam. Sampel diambil dari kelas XI IPS 1 dan XI IPS 2. Kelas XI IPS 1 dijadikan sebagai kelas eksperimen atau kelas yang diberikan pengajaran menggunakan atlas elektronik dan XI IPS 2 dijadikan sebagai kelas kontrol yaitu kelas yang menggunakan atlas.

Berdasarkan data hasil penelitian dan analisis data menunjukan bahwa terdapat perbedaan hasil belajar antara siswa pada kelas eksperimen yang diajarkan dengan menggunakan atlas elektronik dengan siswa kelas kontrol yang diajarkan tidak menggunakan atlas elektronik atau hanya menggunakan atlas. Hasil belajar dengan menggunakan atlas elektronik lebih tinggi dibandingkan dengan hasil belajar siswa yang tidak menggunakan atlas elektronik.

Pada saat pre tes nilai rata-rata siswa kelas eksperimen yaitu 54,83 sedangkan nilai rata-rata siswa pada kelas kontrol yaitu 56,21. Jadi, selisih nilai rata-rata antara kelas eksperimen dan kelas kontrol pada saat pre tes adalah sebesar 1,38. Dari hasil tersebut dapat disimpulkan bahwa kemampuan siswa pada kelas eksperimen dan kelas kontrol tidak jauh berbeda. Kemampuan awal kelas eksperimen dan kelas kontrol dapat dikatakan cukup baik karena ratarata siswa mampu menjawab setengah dari soal yang diberikan. Setelah diberikan perlakuan yang berbeda pada kelas eksperimen dan kelas kontrol, dimana kelas eksperimen diberikan pengajaran dengan menggunakan atlas elektronik dan kelas kontrol diberikan pengajaran dengan menggunakan atlas. Kemudian dilakukan post tes yaitu tes dilakukan untuk mengetahui hasil belajar siswa setelah diberikan perlakuan maka dapat diketahui bahwa nilai rata-rata siswa pada kelas eksperimen mengalami peningkatan yang lebih dibandingkan dengan kelas kontrol. Dari hasil penelitian diperoleh nilai rata-rata siswa pada kelas eksperimen pada saat post tes sebesar 80,17 dan pada kelas post tes kelas kontrol diperoleh nilai rata-rata sebesar 72,81. Untuk lebih jelasnya perhatikan tabel di bawah ini. 


\section{Tabel 5. Nilai Rata-Rata Kelas Eksperimen Dan Kontrol}

\begin{tabular}{llll}
\hline Kelas & Pre tes & Post tes & Kesimpulan \\
\hline Eksperimen & 54,83 & 80,17 & Meningkat \\
\hline Kontrol & 56,21 & 72,81 & Meningkat \\
\hline
\end{tabular}

Pada tabel diatas diketahui bahwa terjadi peningkatan nilai rata-rata hasil belajar siswa pada kedua kelas. Tetapi, peningkatan nilai rata-rata siswa pada kelas eksperimen lebih tinggi daripada peningkatan nilai rata-rata dari pre tes ke post tes sebesar 25,34 sedangkan pada kelas kontrol hanya mengalami peningkatan nilai rata-rata sebesar 16,6. Hal ini terjadi karena pada kelas eksperimen yang diperlakukan menggunakan atlas elektronik yang mampu menampilkan peta yang lebih informatif, dan memaparkan persebaran sumber daya alam di Indonesia yang lebih jelas dan detail. Hasil skor pada materi pengertian, jenis-jenis dan pemanfaatan sumber daya alam, baik kelas eksperimen maupun kontrol diberikan perlakuan yang sama. Pemberian perlakuan yang berbeda dilakukan pada materi persebaran sumber daya alam. Kelas eksperimen diberikan perlakuaan atlas elektronik sedangkan kelas kontrol tidak diberikan perlakuaan atau hanya diberikan materi sebagaimana biasanya menggunakan atlas konvensional. Maka, hasil peningkatan rata-rata skor pada kelas kontrol sebesar 8,5 sedangkan pada kelas eksperimen mengalami peningkatan sebasar 17. Kelas eksperimen mengalami peningkatan dua kali lebih tinggi dibandingkan kelas kontrol.

Peningkatan rata-rata skor pada kelas eksperimen lebih tinggi dibandingkan kelas kontrol dikarenakan penggunaan atlas elektronik. Atlas elektronik merupakan media yang membantu siswa dalam memahami sebaran sumber daya alam. Tampilan tayangan yang berwarna, penyertaan pemodelan sebagai jembatan ke arah pemahaman, sehingga mempermudah dan mempercepat siswa menyerap materi pembelajaran. Dalam pembelajaran, atlas elektronik dapat menggambarkan suatu objek yang bergerak bersama-sama dengan suara alamiah atau suara yang sesuai. Kemampuan media audio visual melukiskan gambar hidup dan suara memberikan daya tarik tersediri karena dapat menyajikan informasi, mengajarkan ketrampilan, menyingkat 
atau memperpanjang waktu, dan mempengaruhi hasil belajar.

Selain itu, peningkatan materi persebaran sumber daya alam pada kelas eksperimen ini lebih tinggi di bandingkan materi sumber daya alam yang lain. Dengan peningkatan rata-rata yang lebih tinggi, dapat mempengaruhi hasil belajar yang lebih banyak di bandingkan materi yang lain. Sehingga penggunaan atlas elektronik dapat meningkatkan hasil belajar geografi siswa kelas XI IPS pada materi Sumber Daya Alam.

\section{PENUTUP}

Hasil penelitian menyimpulkan bahwa terdapat pengaruh penggunaan atlas elektronik terhadap hasil belajar siswa kelas XI IPS pada mata pelajaran geografi dengan materi sumber daya alam. Oleh karena itu guru bidang studi geografi dapat menggunakan atlas elektronik ini sebagai salah satu media yang digunakan dalam proses belajar mengajar geografi.

\section{DAFTAR PUSTAKA}

Anderson, L.W. and David R.K, (ed). 2001. A Taxonomy for Learning, Teaching, and Assessing. New York: Addison Wesley Longman, Inc.

Anita, Lusi. 2011. Silabus Geografi SMA Kelas $X I$.

(Online) http://lusianita.blogspot.com/20 11/02/silabus-geografi-smakelas-xi.html. (05 Februari 2011).

Arikunto,Suharsimi. 2005. Dasar-Dasar Evaluasi Pendidikan. Jakarta : PT Rineka Cipta.

Arsyad, Azhar. 2009. Media pembelajaran. Jakarta: PT. RajaGrafindo Persada.

Bastable, Susan B. 2002. Perawat sebagai pendidik: prinsipprinsip pembelajaran dan pengajaran. Jakarta: EGC.

Bintarto, R dan Surastopo Hadisumarno. 1991. Metode Analisa Geografi. Jakarta: LP3ES.

Dimyati dan mudjiono. 2006. Belajar dan pembelajaran. Jakarta: PT Rineka Cipta. 
Djamarah, Syaiful bahri dan Aswan Zain. 2006. Stategi Belajar Mengajar. Jakarta: Rineka Cipta.

Miarso, yusufhadi. 2005. Menyemai Benih Teknologi pendidikan. Jakarta: Kencana_370 Mia

Mulyasa, E. 2007. Kurikulum Tingkat Satuan Pendidikan. Bandung : PT Remaja Rosdakarya.

Purwanto. 2010. Evaluasi Hasil Belajar. Yogyakarta: Pustaka Pelajar_371. 3

Riduwan. 2008. Metode dan Teknik Menyusun Tesis. Bandung : Alfabeta

Sadiman, Arief S. dkk. 2008. Media Pendidikan. Jakarta: PT. Raja Grafindo.

Slameto. 2003. Belajar dan FaktorFaktor yang Mempengaruhinya. Jakarta: Rineka Cipta.

Sudjana. 2005. Metode Statistika. Bandung: Tarsito.
Sudjana, Nana. 2010. Penilaian hasil Proses Belajar mengajar. Bandung: PT. Remaja Rosdakarya.

Sudijono, Anas. 2009. Pengantar Evaluasi Pendidikan. Jakarta: PT. Raja Grafindo Persada.

Sukardi. 2011. Evaluasi Pendidikan Prinsip dan Operasionalnya. Jakarta: PT. Bumi aksara.

Sumaatmadja, Nursid. 1981. Studi Geografi Suatu Pendekatan dan Analisa Keruangan. Bandung : Alumni.

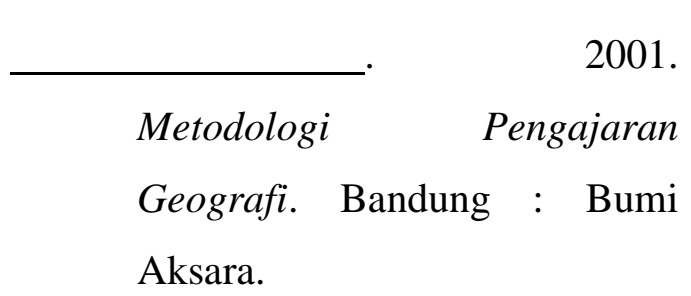

Suryabrata, Sumadi. 1993. Psikologi Pendidikan. Jakarta: PT Raja Grafindo Persada.

Wahyono, Teguh. 2006. Animasi dengan Macromedia Flash 8. Jakarta: PT. Alex Media Komputindo. 